Mr Saša Veselinović, major, dipl. inž

Srđan Milenković, potpukovnik Uprava za organizaciju MO, Beograd

\section{PRAVCI RAZVOJA AUTOMATIZACIJE INFORMACIONOG SISTEMA ODRŽAVANJA U VOJSCI SRBIJE I CRNE GORE}

\author{
UDC: $62-7: 004.38: 004.4$
}

Rezime:

Postojeći informacioni sistem održavanja u Vojsci je, uz određene modifikacije, zadržan još iz perioda posle Drugog svetskog rata. Bilo je nekoliko pokušaja da se izvrši automatizacija, ali su svi pokušaji propali, bilo zbog pogrešnog pristupa ili pogrešnog izbora programskih alata. Reforme u Vojsci imaju značajan uticaj na organizaciju sistema održavanja, ali je uticaj na informacioni sistem održavanja neznatan. Prvi korak u automatizaciji predstavlja detaljna analiza procesa i tokova podataka čiju obradu treba automatizovati. Da bi automatizacija bila uspešna, analiza i deskripcija procesa i tokova podataka treba da bude radena u nekom od savremenih paketa za izradu informacionih sistema. Model informacionog sistema održavanja, opisan sa 19 potprocesa, nudi jedan od mogućih načina za automatizaciju, što je i potvrdeno kroz program „, Automatizovani informacioni sistem održavanja - trupni nivo". Ukoliko sistem odbrane naše zemlje teži međunarodnim integracijama, mora imati kompatibilne informacione sisteme, koji se mogu projektovati, kupiti ili ih mogu nametnuti medunarodne organizacije.

Ključne reči: informacioni, održavanje, automatizacija, program, proces, trupni, model.

\title{
AUTOMATIZACION DEVELOPMENT DIRECTIONS OF MAINTENANCE INFORMATION SYSTEM IN THE MILITARY FORCES OF SERBIA AND MONTENEGRO
}

Summary:

Available maintenance information system in the military forces is, with some modification, retained from the period after the World War II. There were several attempts of automatization of maintenance information systems, but all the attempts failed, whether because of the wrong approach or the wrong choice of program tools. A reform in military forces has got an important influence on organization of maintenance system, but the influence on the maintenance information system is minor. The first step in automatization is detailed analysis of processes and the data flow that should be automated. For successful automatization, the analysis and process description ND data flow should be made in some of the modern systems for information systems production. The model of maintenance information system, described with 19 sub-processes, offers one of the many possible ways for automatization, which is verified through the program „Automatization informational system of maintenance - troop level ". If system of national defence wants to enter the international integrations, it must have compatible information systems that can be made, bought or imposed by the international organizations.

Key words: informacional, maintenance, automatization, program, process, troop, model.

\section{Uvod}

Održavanje tehničkih materijalnih sredstava u našoj vojsci prvobitno je organizovano po ugledu na oružane snage
SSSR-a. U kasnijem razvoju detaljno su analizirana sopstvena dostignuća i dostignuća savremenih armija (pre svega SSSR i SAD), a pozitivna iskustva, primenjiva $u$ našoj praksi, implementirana su u sistem. 
Izmene su se, uglavnom, odnosile na razvoj organizacione šeme, a uslovljavane su uvođenjem novih sredstava i novih tehnologija. Izuzetno, promene su se odnosile i na informacione tokove, a bile su posledica promena organizacione strukture Vojske. Bez obzira na sve promene, kako samog sistema, tako i okruženja, struktura funkcija informacionog sistema održavanja i organizacija rada ostajali su nepromenjeni.

Informacioni sistem održavanja (ISOd) $u$ Vojsci Srbije i Crne Gore zasnovan je na prikupljanju podataka, izradi sumarnih pregleda i pisanih analiza $i$ njihovom dostavljanju pretpostavljenoj komandi. Svaki nivo komandovanja, u skladu sa sopstvenom nadležnošću, a na osnovu izvršenih analiza, preduzima upravljačku akciju koja je usmerena na otklanjanje uočenih odstupanja od željenog stanja.

Ovakva organizacija rada održala se dugo, jer bez većih problema obezbeđuje prelazak na ratnu organizaciju, ne zahteva velika materijalna ulaganja, obezbeduje potrebne podatke za upravljanje sistemom i dozvoljava „korigovanje“ rezultata.

Međutim, upravljačke akcije koje se preduzimaju u ovakvom sistemu najčešće su neadekvatne, kako po sadržaju, tako i po vremenu.

Razvoj i uvođenje u operativnu upotrebu savremenih borbenih sistema, zasnovanih na računarskoj tehnologiji, pokazao je niz slabosti informacionog sistema održavanja na koji se oslanjao. Uočeno je da je ovakav sistem zastareo i da ne zadovoljava zahteve savremenih armija, a pre svega zbog: male brzine obrade po- dataka, niske pouzdanosti sistema, usporenih informacionih tokova, kasnih i neadekvatnih upravljačkih akcija.

Analizom aktuelnog sistema ustanovljeno je da je odnos kvaliteta i cene znatno nepovoljniji nego kod većine savremenih armija, pa je trebalo, primenom novih sistema za podršku odlučivanju i računara, razviti automatizovani informacioni sistem održavanja kojim bi bili sniženi troškovi funkcionisanja sistema, a zadržana zahtevana borbena gotovost jedinica.

U skladu sa proklamovanim ciljem, početkom 1990. godine, na nivou Vojske, formiran je stručni tim iz oblasti održavanja, koji je trebalo da izradi projekat „Automatizovani informacioni sistem održavanja“, koji bi bio element tehničkog informacionog sistema, podsistema pozadinskog informacionog sistema. Projekat je urađen, ali zbog raspada države i hronične ekonomske krize u Vojsci, nije nikada zaživeo. Kada su se ponovo stekli uslovi za njegovo uvođenje, već je bio zastareo u pojedinim delovima.

Sredinom 1997. godine pokrenut je novi projekat pod nazivom „Informacioni sistem održavanja - ISOd“. Izvršena je analiza sistema, ali projekat nikad nije završen do kraja, uglavnom zbog paralelnog (istovremenog) pristupa u projektovanju, što je zahtevalo visoke materijalne troškove razvoja i uvođenja u eksploataciju. I pored toga što je projekat ostao u sferi teoretskih razmatranja i nije rezultirao realnim modelom, neki od zaključaka iz analize funkcionisanja sistema održavanja mogu se smatrati opštim i trajno važećim. 
Pre svega, za razliku od Vojske koja ima organizacionu strukturu, na tri nivoa, sistem održavanja ima organizacionu šemu koja se sastoji od četiri nivoa, a to su: nivo korisnika, taktički (trupni), operativni i strategijski nivo.

Analizom sistema održavanja tehničkih sistema uočava se da je on na trupnom (taktičkom) nivou relativno jednostavan, a ujedno i zaokružen, i da se ponavlja u svakoj jedinici sa samostalnom formacijom. Na ovom nivou vrši se direktna komunikacija između korisnika i sistema održavanja, kao i evidentiranje i početna obrada podataka. Evidentno je da bi se najveći pomak u automatizaciji učinio ako bi se razvoju novog informacionog sistema pristupilo po principu serijske realizacije "odozdo nagore“ (down-up), čime bi prednosti sistema bile odmah uočljive na trupnom nivou, a zahtevana materijalna sredstva bila bi najmanja. Problem ovakvog pristupa, moguća raznorodnost tehničke platforme i programskih paketa, bio bi otklonjen tako što bi se upravljanje razvojem obavljalo sa jednog mesta.

Operativni i strategijski nivo rukovode i upravljaju snagama i sredstvima u sistemu održavanja. Za realizaciju svojih osnovnih funkcija oni treba da raspolažu validnim informacijama. Zato je u svim informacionim tokovima neophodno razviti visok nivo integriteta podataka, potrebnu brzinu i kapacitet prenosa kako bi sistem delovao u realnom vremenu, i posebno pouzdan informacioni sistem $u$ kojem bi broj i vreme otkaza bili svedeni na najmanji mogući nivo.

Pri projektovanju novog informacionog sistema potrebno je proučiti i način organizovanja i funkcionisanja sistema održavanja u savremenim armijama kao i njihova iskustva.

Savremeni inostrani informacioni sistemi održavanja koncipirani su na nivou servisa (tehničke radionice) i omogućavaju povezivanje sa korisnicima putem Interneta. Njima se omogućava automatizovano planiranje održavanja na osnovu eksploatacionih parametara i statističkog predviđanja otkaza, i automatizovano praćenje stanja rezervnih delova.

Vojna primena ovih aplikacija odnosi se na povezivanje automatizovanog informacionog sistema održavanja sa Globalnim sistemom pozicioniranja (GPS). Time se omogućava da sredstvo izvrši samodijagnostiku, prijavi neispravnost i vlastitu poziciju na bojištu.

\section{Uticaj organizacijskih promena Vojske na informacioni sistem održavanja na trupnom nivou}

Započete reforme Vojske mogu imati manji ili veći uticaj na funkcionisanje sistema održavanja, a samim tim i informacioni sistem održavanja. S obzirom na to da reforma predstavlja korenite promene odnosa sistema i okruženja, kao i promene organizacione strukture samog sistema, nesumnjivo je da će ona imati značajan uticaj i na sistem održavanja. Generalno opredeljenje da logistika u Vojsci bude zasnovana na funkcionalnom pristupu upućuje i na promene u sistemu održavanja. Promena organizacione strukture jedinica za održavanje tehničkih materijalnih sredstava (TMS) eksplicitno ce se odraziti i na promenu strategije održavanja. 
Osnovni cilj reforme jeste da bude stvorena dobro naoružana i efikasna Vojska, sposobna da odgovori svim eventualnim izazovima, rizicima i pretnjama koji su usmereni na bezbednost državne zajednice, ali i da svoju organizacionu strukturu prilagodi savremenim zahtevima i pripremi se za priključenje Evroatlantskim bezbednosnim asocijacijama.

Armije zemalja koje su pristupile Evroatlantskim asocijacijama svoju organizacionu šemu zasnivaju na bataljonu divizionu, kao osnovnoj jedinici, a puk brigada su modularnog tipa. Bataljoni divizioni formirani su kao potpuno samostalne jedinice i u miru su potčinjeni rodovskim mirnodopskim komandama koje vrše obuku jedinica. Takođe, u miru postoje i ratne komande brigada koje nemaju potčinjene sastave. Za izvršenje konkretnih zadataka formiraju se privremeni sastavi organizovani od bataljona - diviziona (iz organizacijskog sastava mirnodopskih rodovskih brigada) i upućuju na zadatak ili se pretpotčinjavaju ratnim komandama brigada. Ovakav pristup podrazumeva visok stepen profesionalizacije i opremljenost savremenim naoružanjem i opremom. Prelazak Vojske na ovakvu organizaciju predstavlja realnu mogućnost.

Kada je u pitanju tehničko održavanje (TOd), to bi značilo da svaki bataljon mora biti samostalan u održavanju. U organizacijskom smislu to pretpostavlja da svaki bataljon u svom ogranizacijskom sastavu mora da ima tehnički vod sastavljen od odeljenja za održavanje i odeljenja za snabdevanje. Na brigadnom nivou bila bi formirana manja jedinica za održavanje koja bi obavljala samo određene radove: opravku i pregled precizne mehanike, optike, centralizovan dotur rezer- vnih delova i potrošnog materijala, itd. Nosilac TOd u ovom slučaju bio bi bataljon - divizion.

Druga mogućnost je da se u miru od vodova za tehničko održavanje formira privremena jedinica na nivou rodovskog puka - brigade, kada bi nosilac tehničkog održavanja bila komanda puka - brigade.

Promene u strategiji održavanja, za razliku od organizacijskih promena koje se usklađuju sa društvenim zahtevima, zasnovane su na težnji da se smanji broj preventivnih radnji održavanja i produži korišćenje delova i sklopova do krajnje granice, a da se zamena vrši neposredno pred otkaz (to se odnosi na skupa sredstva i sredstva bitna za borbenu gotovost). Da bi se to postiglo potrebno je jedinice opremiti savremenim sofisticiranim sredstvima koja imaju mogućnost samodijagnostike ili mogućnost da se priključkom na računarsku opremu izvrši očitavanje eksploatacionih parametara koji mogu ukazivati na dotrajalost ili neispravnosti vitalnih sklopova. Ovakav pristup uslovljava i promene $\mathrm{u}$ sistemu obučavanja, pa je potrebno stručnospecijalističko školovanje kadrova usmeriti prema opremi, a ne prema strukama radne snage.

Bez obzira na izabranu organizacionu šemu Vojske, u svakom od mogućih organizacionih oblika i strategija održavanja, uvek postoji jedinica za TOd i njoj pretpostavljena komanda koja je nosilac TOd. Bilo da se radi o jedinici za tehničko održavanje u sastavu samostalnog bataljona - diviziona ili o koncentraciji tih jedinica u mirnodopskoj rodovskoj brigadi, uvek postoji komandir jedinice i odeljenja koje izvode radove tehničkog održavanja, kao i preventivno održavanje - 
kontrolu stanja, a korisnici mogu zahtevati tehničko održavanje na osnovu eksploatacionih parametara. Sagledavanjem uticaja reformi oružanih snaga na informacioni sistem održavanja na trupnom nivou uočava se da je on neznatan.

\section{Procesi informacionog sistema održavanja na trupnom nivou}

Osnovni preduslov automatizacije informacionog sistema održavanja jeste kvalitetna analiza sistema.

Analizom funkcionisanja organizacije održavanja na trupnom nivou, sa stanovišta informacionog sistema, uočava se da se u informacionom sistemu odvija dvadeset međusobno zavisnih procesa, i to [3]:

1. Prijava sredstva u sistem TOd

2. Ažuriranje evidencija i šifarnika

3. Izrada godišnjeg plana održavanja

4. Izrada zahteva za TOd i ispomoć osnovnom održavanju

5. Izrada Mesečnog plana rada jedinice za TOd

6. Izrada nedeljnog plana rada jedinice za TOd

7. Pozivanje i obaveštavanje jedinica korisnika

8. Poručivanje rezervnih delova i potrošnog materijala

9. Izrada dnevnog plana rada jedinice za TOd

10. Prijem sredstva na tehničko održavanje

11. Otvaranje radioničke dokumentacije

12. Trebovanje i izuzimanje rezervnih delova i potrošnog materijala

13. Realizacija tehnološkog programa održavanja
14. Ažuriranje radioničke dokumentacije

15. Predaja sredstva korisniku

16. Zaključivanje radioničke dokumentacije

17. Izrada prijave za srednji remont, generalni remont $\mathrm{i}$ ispomoć TOd

18. Prijem nabavljenih rezervnih delova i potrošnog materijala

19. Izrada izveštaja TOd

20. Arhiviranje.

Redosled i međuzavisnost ovih procesa $u$ informacionom sistemu održavanja, na trupnom nivou, prikazani su na slici 1 .

Analizom navedenih procesa dolazi se do informacionih tokova koje treba automatizovati, ali i do problema čije rešavanje mora da prethodi automatizaciji procesa. Neki od tih problema su da ne postoji jedinstveni standard za nomenklaturu TMS, veliki broj sredstava u sistemu održavanja nema fabrički - serijski broj, ne postoji normativ za veliki broj TMS, postojeći obrasci su predviđeni za centralizovanu obradu podataka, itd.

Pored analize sistema održavanja na trupnom nivou, za automatizaciju je bitna $\mathrm{i}$ analiza podataka potrebnih za upravljanje na svim nivoima komandovanja. Analizom se može ustanoviti da je deo potrebnih izveštaja već propisan i izrađuje se, deo je propisan, ali se ne izrađuje, a jedan deo je predviđen nekim projektima, ali njihova izrada postojećim načinom rada nije moguća.

\section{Izveštaji u sistemu tehničkog održavanja na trupnom nivou}

Analizom postojećih izveštaja i anketiranjem komandnog kadra ustanovljeno je da su izveštaji koje je u automatizo- 


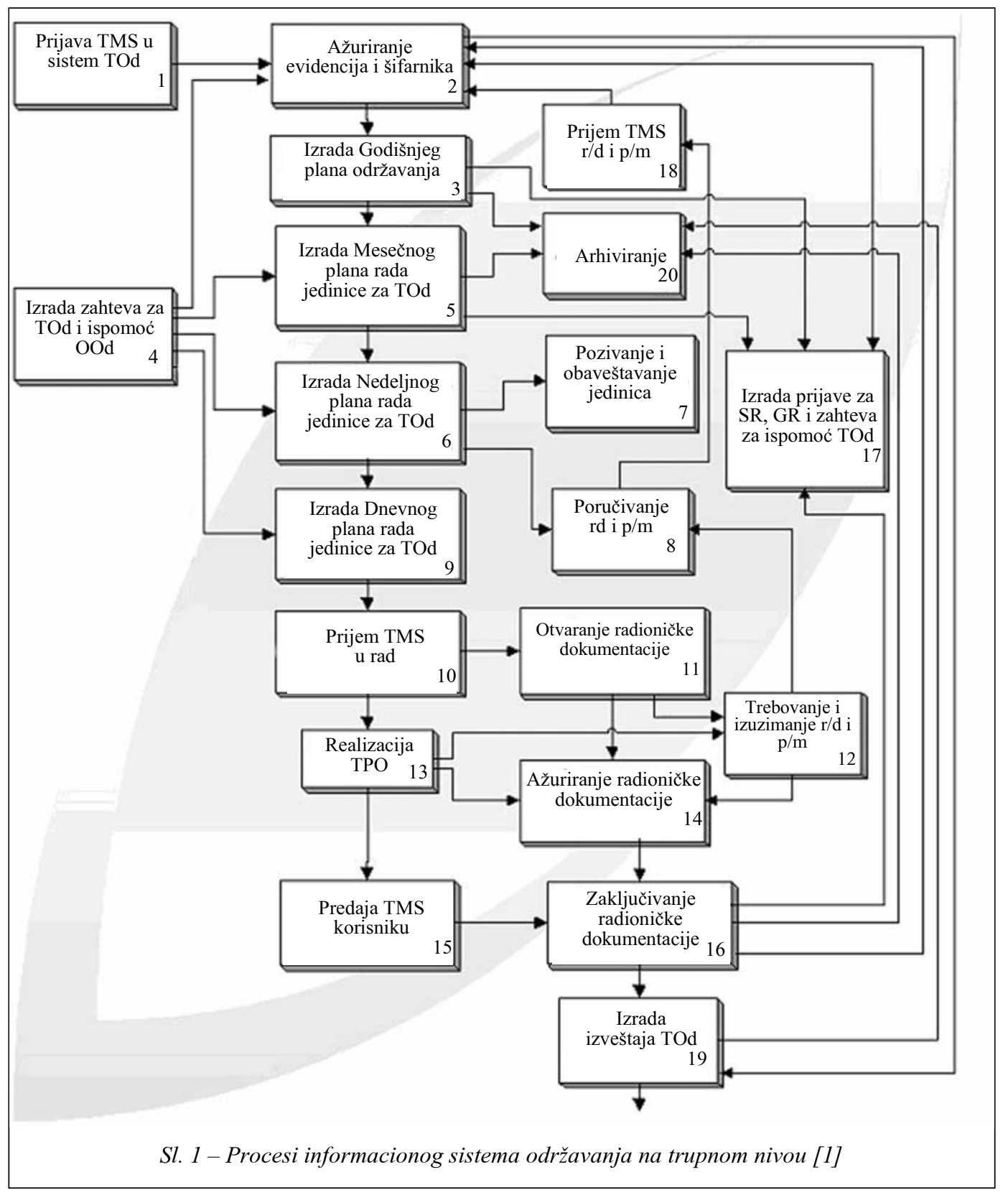

vanom informacionom sistemu održavanja moguće izraditi, kako bi zadovoljili - realizacija Mesečnog plana rada potrebe svih nivoa upravljanja održavanjem, sledeći [2]:

- realizacija Godišnjeg plana tehničkog održavanja, jedinice za TOd,

- pregled radnih naloga u određenom periodu,

- pregled nedostajucíh rezervnih delova i potrošnog materijala, 
- pregled rezervnih delova koji su uzrokovali neispravnosti i nedostajali su u procesu održavanja tehničkih sistema u određenom periodu,

- pregled utrošenih rezervnih delova u procesu održavanja tehničkih sistema,

- pregled realizacije trebovanja rezervnih delova, pneumatika, cerada, stema,

- pregled neispravnih tehničkih si-

- pregled tehničke ispravnosti tehničkih sistema,

- reklamacija,

- izveštaj o vanrednom oštećenju tehničkih sistema,

- pregled vanrednih oštećenja tehničkih sistema,

- pregled stanja resursa tehničkih sistema za srednji remont,

- pregled stanja resursa tehničkih sistema za generalni remont,

- pregled realizacije plana TOd tehničkih sistema,

- pregled strukture ostvarenog kapaciteta i gubitaka u tehničkim radionicama,

- pregled angažovanja kapaciteta izvan jedinice (za ispomoć),

- pregled popunjenosti ljudstvom za tekuću godinu,

- pregled potrebnih i raspoloživih kapaciteta za održavanje i remont u tekućoj godini,

- izvod nepokrivenih količina tehničkih sistema u periodu,

- izvod nepokrivenih specijalnosti iz sistema održavanja u određenom periodu, TMS,

- pregled parametara održavanja

- izveštaj o parametrima eksploatacije, održavanja i remonta tehničkih sistema ranga 1 ,

- izveštaj o stanju održavanja tehničkih sistema.
Pored ovih izveštaja, moguće je uvesti i druge pomoćne izveštaje koji su potrebni u sistemu, kao što su: pregled angažovanja mehaničara po danima i zbirno za određeni period, pregled reklamacija na radove po mehaničarima, pregled radioničkih lista za naplatu, itd.

\section{Automatizacija procesa održavanja}

Programski paket koji treba da automatizuje procese održavanja na trupnom nivou trebalo bi da zadovolji nekoliko zahteva.

Prvi i osnovni zahtev jeste da odnos kvaliteta i cene bude na nivou savremenih programskih paketa, a da finansijski troškovi budu usaglašeni sa realnim mogućnostima Vojske. U troškove spadaju cene: izrade programa, obezbeđenja potrebnog hardvera, implementacije programa, obuke kadrova za rad na sistemu, održavanja i dogradnje i razvoja automatizovanog informacionog sistema.

Drugi zahtev jeste da program u realnom vremenu daje izveštaje koji mogu da se koriste za adekvatno upravljanje sistemom održavanja na trupnom nivou.

Treći zahtev je da razvoj programa ne traje predugo. Postoje programi koji se razvijaju godinama i stalno se dograđuju, ali od njih nema nikakve koristi, jer ne ulaze u primenu. To znači da nije izvršena kvalitetna sistemska analiza [1] ili da je izabran pogrešan alat za razvoj programa.

Da bi programski paket odgovarao informacionom sistemu, kao i da je moguće buduće promene implementirati, potrebno je, u nekom od alata za projektovanje, opisati proces koji se automati- 
zuje. Prednost primene ovih alata je u tome što omogućavaju da eksperti iz oblasti informatike shvate proces koji treba da automatizuju, da korisnici ukažu na nedostatke programa, a da sistem-inženjeri uoče nedostatke postojeće organizacije. Takođe, ovi alati omogućavaju i automatsko kreiranje baze podataka u nekom od paketa koji služi za izradu relacionih i objektnih baza podataka, kao i sinhronizaciju u slučaju izmene u modelu procesa.

Izbor programa za automatizaciju informacionih sistema održavanja zavisi od više faktora, od kojih su najbitniji: cena, mogućnost prilagođavanja potrebama korisnika, tehnička podrška, ponuđene beneficije. Ipak, razliku između isplativog i neisplativog informacionog sistema čini kompromis između cene i mogućnosti da sistem obezbedi kvalitetne podatke za upravljanje sistemom.

Dobri informacioni sistemi imaju karakteristiku da, pored praćenja održavanja, kao neodvojivi deo procesa, prate i promet rezervnim delovima. U programima koji su analizirani, veliki deo svakog od njih posvećen je praćenju stanja u skladištu, utrošku, poručivanju i prijemu rezervnih delova.

Druga karakteristika dobrih informacionih sistema održavanja jeste da omogućavaju planiranje preventivnog održavanja na osnovu vremenskih resursa i na osnovu eksploatacionih merenja. Pojedini programi omogućavaju i statističko predviđanje eksploatacionih parametara i, na osnovu toga, može se zakazati aktivnost preventivnog održavanja.

Sagledavanjem važeće normativno-pravne regulative, potreba komandi na raznim nivoima komandovanja, kao i mogu- ćih promena u sklopu reforme Vojske, može se videti da većina informacija koje su potrebne za upravljanje postoje u sistemu održavanja. Deo ulaznih dokumenata iz projekta AISO implementiran je u postojeći informacioni sistem održavanja na trupnom nivou. Problemi nastaju u praksi, jer su obrasci prilagođeni automatizovanoj obradi podataka čija automatizacija nikada nije izvršena. Drugi problem je funkcionisanje sistema održavanja u realnim uslovima, koji izlazi iz okvira propisanog.

Alati koji se najčešće koriste za ove potrebe su programski paket BPWin i ERWin ili programski paket Rational Rose. BPWin služi za opisivanje procesa, a ERWin za kreiranje logičkog i fizičkog modela podataka, (to su programi starije generacije), dok je Rational Rose noviji paket i umnogome složeniji, jer objedinjava funkcije oba ova programa.

Sledeći paket koji je potrebno izabrati je paket u kojem ce biti baza podataka. Budući da je u pitanju složen sistem sa više nivoa grupisanja podataka i više korisnika, alat mora podržavati baze podataka u višekorisničkom režimu rada. Ovakvih paketa ima više, a najpoznatiji su ORACLE, MS SQL i ACCESS. ORACLE i MS SQL mogu da služe za razvoj klijent-serverskih aplikacija, dok ACCESS to ne može. Međutim, ACCESS omogućava da do 5 korisnika istovremeno rade nad istom bazom podataka i omogućava brz razvoj aplikacija pomoću veoma kvalitetnih i intuitivnih ,čarobnjaka“. Razvoj aplikacija uključuje i izradu potrebnog interfejsa i izveštaja u obliku tabela ili dijagrama, kao i alata za administriranje baze, a nije potrebna kupovina posebnog softvera, jer je on već uključen u registrovane pakete MS Office. 


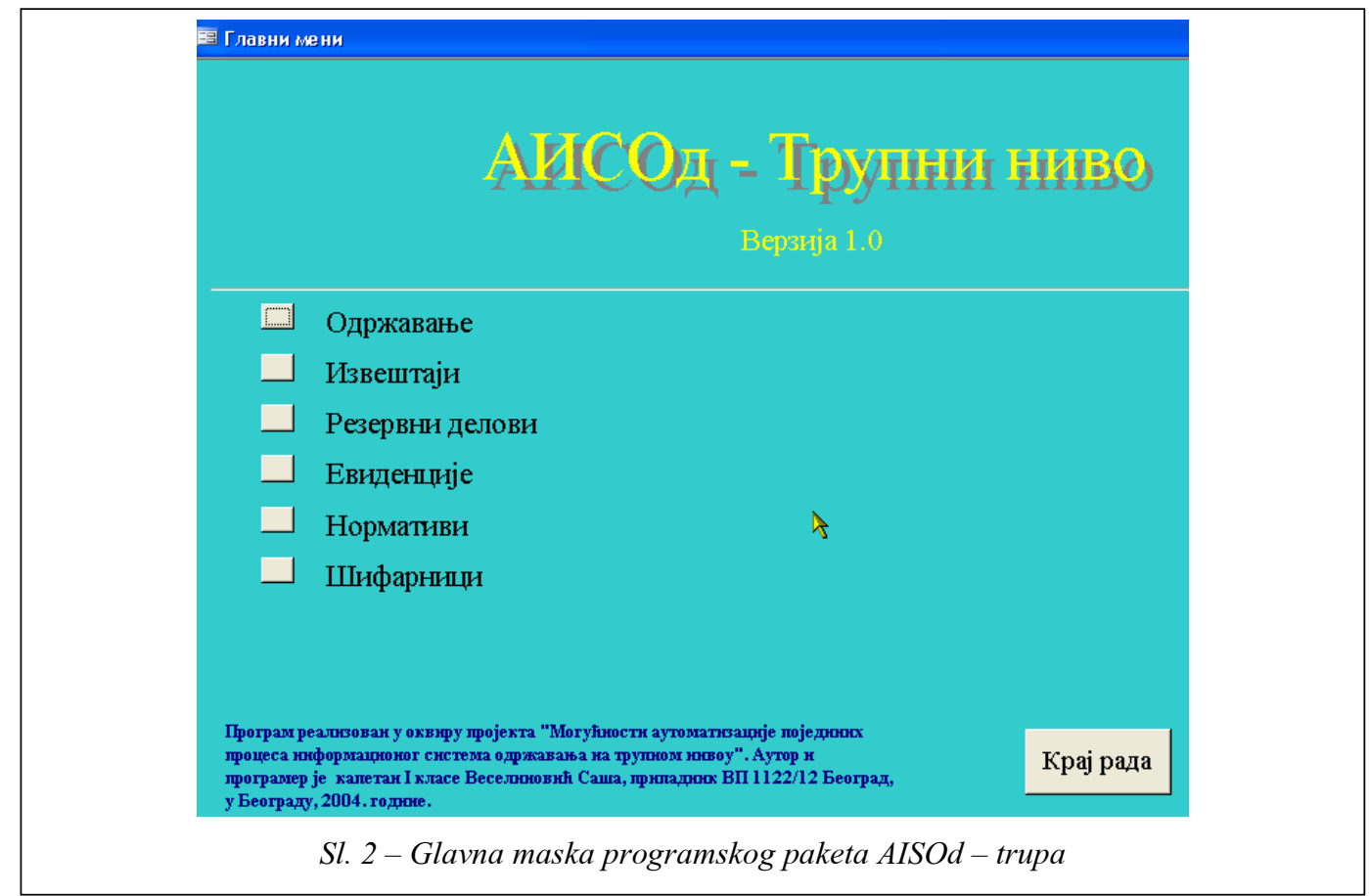

U literaturi [3] dat je model podataka koji opisuje informacioni sistem odrŽavanja na trupnom nivou, na način koji omogućava njegovu automatizaciju. U istom radu urađena je $\mathrm{i}$ aplikacija (AISOd - trupni nivo) koja u osnovnom obliku eksperimentalno dokazuje da je moguća automatizacija predloženog informacionog sistema.

\section{Automatizovani informacioni sistem održavanja - trupni nivo}

Pri startovanju programa AISOd trupa 1.0, pokreće se uvodna maska prikazana na slici 2. Podmaske su grupisane prema funkcijama: održavanje, izveštaji, rezervni delovi, evidencije, normativi i šifarnici.

Podmeni „održavanje“ ima sledeće opcije: proizvodno ljudstvo, planovi održavanja, radionička lista, zahtevi - zagla- vlja, zahtevi stavke, reklamacija, vanredno oštećenje.

U podmeniju „održavanje“ omogućeno je unošenje podataka o proizvodnom ljudstvu, zahtevima prema jedinici za TOd, izrada planova (dnevnih, nedeljnih, mesečnih - slika 3 i godišnjih), analize planova, radioničke dokumentacije i izveštaja o reklamaciji i vanrednom oštećenju.

Izrada planova i analiza je poluautomatizovana kao i izrada radioničke dokumentacije. Iz radioničke dokumentacije moguće je kreirati ML-LIP i u njega uneti podatke o rezervnim delovima jednostavnim izborom iz imenika.

Radionička lista (slika 4) sačinjena je tako da sadrži sve podatke o eksploataciji svih sredstava koja dođu na održavanje, ali se podrazumeva da sva sredstva imaju serijski ili registarski broj. Radioničke liste povezane su sa stavkama plana, a ako nisu povezane onda se tretiraju 


\begin{tabular}{|c|c|c|c|c|c|c|c|c|c|c|}
\hline$=$ & & & & & & & & & & \\
\hline$O Д O B$ & $A B A$ & $\Pi n$ & an odpow & жекња: МП & & & & & & 1.2 .2004 \\
\hline Imax Mrip & KKOBнћћ Eor & дан & & & & & & demyse & & 282.2004 \\
\hline BRIedO & & $7552 / 32$ & & & & & & & & \\
\hline HazueJ & & Техтичго вод & & & & & & & & \\
\hline $\mathrm{OBCm}$ & $B \Pi K_{O P}$ & Hazue $T M C$ & $T \pi O$ & Onuc scomeane axmuenocmsi & Bamys Od & Kan & PKon & PПHY & $T p M$ & $\%$ pean \\
\hline Ontos & Mrroprum & 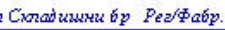 & Henpartoom & & Датуш До & $\Pi H \Psi$ & & $O E Y$ & $T p P C$ & Thpod. \\
\hline a & 1552116 & Tel kcpedta IISt & תp & 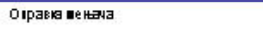 & 1322004 & 1 & 1 & 10 & & $1 \omega \mathbf{m} \%$ \\
\hline & 0 & $7569-9696-96099$ & $\mathrm{EC}$ & & $15220 \mathrm{~m}$ & a & & 17 & $5.43,40011$. & $59 \%$ \\
\hline 1 & 155203 & 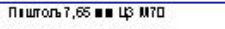 & IITก & IITत & 1.12004 & 2 & & & & \\
\hline $3 n$ & a & $1111-1111-1111-1$ & $\mathrm{EC}$ & & $28.12 \mathrm{mt}$ & 0,4 & & & & \\
\hline 2 & 155205 & 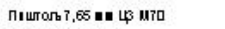 & ॥ & $\| \mathrm{T \Pi}$ & $12 \pi 0 \mathrm{at}$ & 1 & & & & \\
\hline гп & a & $1111-1111-1111-1$ & $\mathrm{EC}$ & & $2822 \mathrm{~m} t$ & 0,2 & & & & \\
\hline 3 & 155205 & 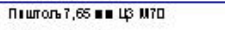 & IITก & 111 & 1.120104 & 3 & & & & \\
\hline $3 \pi$ & 0 & $1111-1111-1111-1$ & $\mathrm{BC}$ & & $28.12 \mathrm{~m}$ & 0,5 & & & & \\
\hline 4 & 155205 & 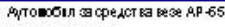 & ITח & ITח & 1.12004 & 1 & 1 & 7 & $7.10550 \mathrm{Dll}$ & $1 \varpi \%$ \\
\hline $3 \pi$ & a & $1111-1555-6066-6$ & $\mathrm{EC}$ & & $28.12 \mathrm{~m}$ & 7 & & 7 & $2.241,4001 \mathrm{ot}$. & $1 \omega \pi$ \\
\hline
\end{tabular}

Sl. 3 - Izgled dela izveštaja o realizaciji Mesečnog plana održavanja TMS

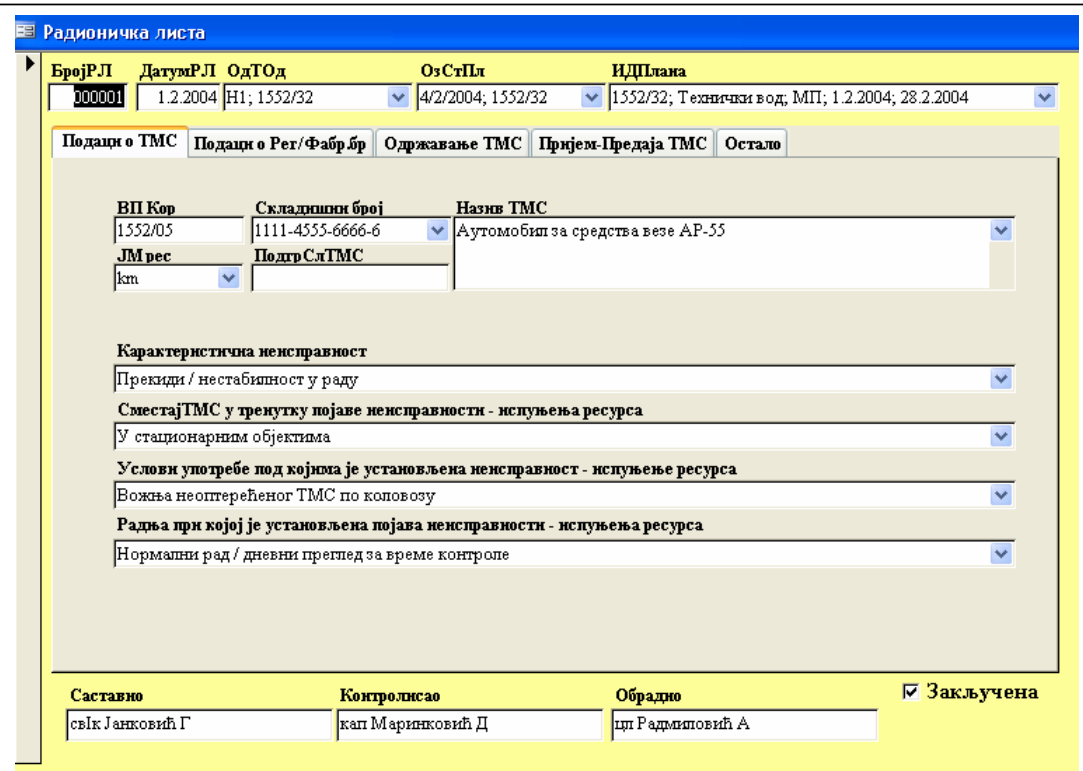

Sl. 4 - Maska za unos podataka u obrazac radioničke liste

kao vanplanske. Pri svakom otvaranju stavki plana, realizacija se ažurira.

U podmeniju ,izveštaji“ svi izveštaji su grupisani u tri podmenija: analiza stanja, realizacija održavanja i izveštaji rezervni delovi.

Podmeni ,analiza stanja“ omogućava izradu sledećih izveštaja:

- pregled broja vanrednih oštećenja,
- pregled nepokrivenih količina tehničkih sistema,

- pregled nepokrivenih struka u sistemu održavanja, pacitetima,

- pregled popune proizvodnim ka-

- pregled potrebnih i raspoloživih godišnjih kapaciteta,

- izveštaj TS1-2. 
Podmeni „realizacija održavanja“ omogućava izradu izveštaja koji su vezani za održavanje, a to su:

- pregled angažovanih kapaciteta van jedinice (za ispomoć), lista,

- pregled nezaključenih radioničkih

- pregled parametara održavanja tehničkih sredstava,

- pregled radioničkih lista,

- pregled realizacije tehničkog pregleda i konzervacije,

- realizacija kapaciteta (slika 5).

U podmeniju ,izveštaji - rezervni delovi“ grupisani su izveštaji koji su vezani za rezervne delove, $\mathrm{i}$ to:

- pregled nedostajućih rezervnih delova i potrošnog materijala,

- pregled rezervnih delova uzročnika neispravnosti koji su nedostajali,

- pregled realizacije trebovanja rezervnih delova i potrošnog materijala,

- pregled utrošenih rezervnih delova i potrošnog materijala.

Podmeni rezervni delovi sadrži određene potceline. To su: imenik delova, ML-LIP, evidencija rezervnih delova, identifikacione kartice rezervnih delova,

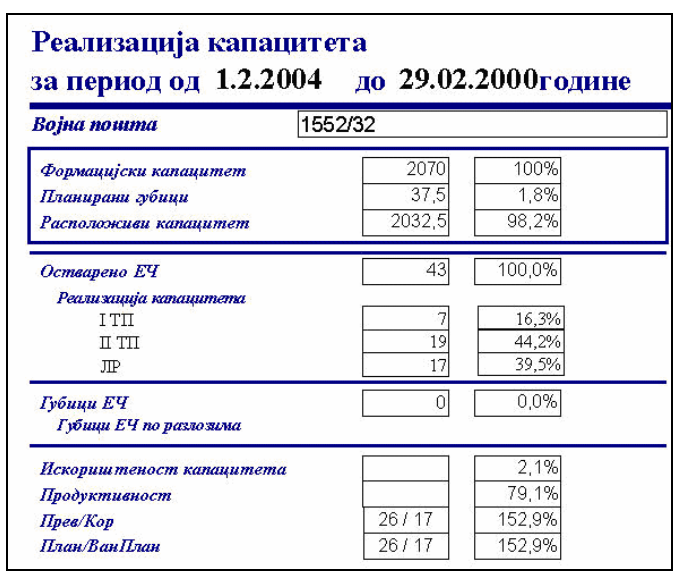

Sl. 5 - Izveštaj o realizaciji kapaciteta porudžbenice rezervnih delova i proizvođači rezervnih delova.

Ovaj deo programa omogućava unos šifarnika rezervnih delova, prati stanje u skladištu i omogućava poručivanje, zaduživanje i razduživanje rezervnih delova. Takođe, omogućena je automatska izrada porudžbenice za rezervne delove, čija je količina ispod definisane tačke naručivanja.

Podmeni ,evidencije“ sadrži šifarnike koji su potrebni za rad automatizovanog informacionog sistema održavanja. U ovom delu programa unose se podaci o jedinicama - ustanovama koje vrše održavanje, sledujućem stanju tehničkih materijalnih sredstava, kao i podaci iz tehničke knjižice - kartona tehničkih materijalnih sredstava.

Podmeni „normativi“ omogućava unošenje i ažuriranje propisanih normativa za aktivnosti održavanja i vremenskih i eksploatacionih resursa po sredstvima $i$ vidovima održavanja.

\section{Zaključak}

Uporedo sa razvojem informacionih tehnologija razvijali su se i informacioni sistemi održavanja, koji imaju zadatak da obezbede kvalitetne informacije potrebne za upravljanje sistemom održavanja.

U Vojsci je, i pored više pokušaja automatizacije, u funkciji manuelni način obrade podataka $\mathrm{u}$ informacionom sistemu održavanja na trupnom nivou. Ovakav sistem ne zadovoljava ni minimalne potrebe za kvalitetnim upravljačkim informacijama. Ostvarenje cilja ovog rada postignuto je kroz: sagledavanje nivoa dostignute automatizacije informacionog sistema održavanja u Vojsci; analizu postojećeg informacionog sistema održava- 
nja (kroz model procesa, model podataka i model resursa) sa predlogom procesa koje je moguće automatizovati bez ili uz izmenu važeće normativno-pravne regulative, i prezentaciju jednog od mogućih pravaca $u$ automatizaciji procesa održavanja na trupnom nivou. I, na kraju, dat je praktičan prikaz mogućeg modela programa za automatizaciju informacionog sistema održavanja na trupnom nivou.

U svetu postoje mnogi programi za automatizaciju informacionih sistema održavanja. Oni su koncipirani tako da automatizuju rad na nivou servisa za održavanje, bez obzira na to da li je sistem održavanja osnovna ili sporedna delatnost. Veliki industrijski kompleksi ulažu ogromna novčana sredstva u razvoj informacionih sistema održavanja, jer im oni omogućavaju adekvatnu reakciju na stanje sistema i okruženja, a sve u funkciji snižavanja troškova proizvodnje i obezbeđivanja konkurentnosti na tržištu.

Zbog toga je potrebno sagledati realne uslove i izmeniti propise koji regulišu predaju tehničkih sistema na popravku po prioritetu, kriterijuma za ustanovljavanje ispravnosti sredstava, način izdavanja rezervnih delova, pozivanja jedinica na održavanje, načina otvaranja i čuvanja tehničke dokumentacije i dr. Ove probleme potrebno je rešiti bez obzira na način obrade podataka. Bez njihovog rešavanja, kao i formalizacije i drugih procesa u sistemu održavanja, razvoj informacionog sistema praktično je nemoguć.

Ukoliko naša zemlja i Vojska želi u Evroatlantske integracije, mora se automatizovati informacioni sistem održavanja, tako da bude kompatibilan sa informacionim sistemima zemalja članica NATO. To se može uraditi onako kako nama odgovara ili će se sačekati trenutak kada će rešenje za automatizaciju biti nametnuto i kada će čitav sistem morati da se prilagođava nametnutim aplikacijama.

\section{Literatura:}

[1] Pavlić, M.: Sistem analiza i modeliranje podataka, Naučna knjiga, Beograd,1990.

[2] Grupa autora: Automatizovani informacioni sistem održavanja, Projekat, 1, vojna oblast, Beograd, 1990.

[3] Veselinović, S.: Mogućnosti automatizacije pojedinih procesa informacionog sistema održavanja na trupnom nivou, magistarski rad, ŠNO, Beograd, 2004

[4] Phillippi, N.: Avoid the Hype in CMMS Selection, Application Resource Consulting Inc., http://www.cmmscity.com articles/avoid_cmms_hype.htm, 2003.

[5] Stanojević, P.; Mišković, V.: Mogućnosti i problemi primene savremenih strategija održavanja u vojnim sistemima, VA ŠNO, radni materijal, 2003. 